\title{
The history of arsenical pesticides and health risks related to the use of Agent Blue
}

\author{
Vladimir Bencko', Florence Yan Li Foong ${ }^{1}$ \\ ${ }^{1}$ Institute of Hygiene and Epidemiology, First Faculty of Medicine, Charles University, Prague, Czech Republic
}

Bencko V, Yan Li Foong F. The history of arsenical pesticides and health risks related to the use of Agent Blue. Ann Agric Anviron Med. 2017; 24(2): 312-316. https://doi.org/10.26444/aaem/74715

\begin{abstract}
Arsenicals in agriculture. Beginning in the 1970s, the use of arsenic compounds for such purposes as wood preservatives, began to grow. By 1980, in the USA, 70\% of arsenic had been consumed for the production of wood preservatives. This practice was later stopped, due to the US Environmental Protection Agency (EPA) ban of the arsenic-and chromium-based wood preservative chromated copper arsenate. In the past, arsenical herbicides containing cacodylic acid as an active ingredient have been used extensively in the USA, from golf courses to cotton fields, and drying-out the plants before harvesting. The original commercial form of Agent Blue was among 10 toxic insecticides, fungicides and herbicides partially deregulated by the US EPA in February 2004, and specific limits on toxic residues in meat, milk, poultry and eggs, were removed. Today, however, they are no longer used as weed-killers, with one exception - monosodium methanearsonate (MSMA), a broadleaf weed herbicide for use on cotton. Severe poisonings from cacodylic acid caused headache, dizziness, vomiting, profuse and watery diarrhea, followed by dehydration, gradual fall in blood pressure, stupor, convulsions, general paralysis and possible risk of death within 3-14 days.

The relatively frequent use of arsenic and its compounds in both industry and agriculture points to a wide spectrum of opportunities for human exposure. This exposure can be via inhalation of airborne arsenic, contaminated drinking water, beverages, or from food and drugs. Today, acute organic arsenical poisonings are mostly accidental. Considerable concern has developed surrounding its delayed effects, for its genotoxic and carcinogenic potential, which has been demonstrated in epidemiological studies and subsequent animal experiments.

Conclusions. There is substantial epidemiological evidence for an excessive risk, mostly for skin and lung cancer, among humans exposed to organic arsenicals in occupational and environmental settings. Furthermore, the genotoxic and carcinogenic effects have only been observed at relatively high exposure rates. Current epidemiological and experimental studies are attempting to elucidate the mechanism of this action, pointing to the question whether arsenic is actually a true genotoxic, or rather an epigenetic carcinogen. Due to the complexity of its effects, both options remain plausible. Its interactions with other toxic substances still represent another important field of interest.
\end{abstract}

\section{Key words}

arsenicals in agriculture, organic arsenicals use, farmers' health, arsenical pesticides, carcinogenicity, Agent Blue toxicity

\section{INTRODUCTION AND HISTORY}

Arsenic is ubiquitous in nature, in both inorganic and organic compounds. The most common form of its occurrence is as sulfides, in association with the sulfides of ores of other metals, coals and sediments [1]. Today, acute arsenic poisonings are mostly accidental. Chronic exposure to arsenicals results in a wide variety of clinical syndromes. However, considerable concern has developed for its delayed effects, specifically its carcinogenic potential. At the present time, this is the key criterion in assessing the hazard from both environmental and occupational exposures to inorganic arsenic [2-4]. Environmental and occupational toxicology of arsenic, including ecotoxicological aspects of environmental pollution, has been extensively reviewed by several authors [5-8]. Apart from the mentioned comprehensive materials, numerous articles have been published demonstrating the growing interest of authors in this field of research. The extent and orientation of this paper towards the agriculture aspects concerning the use of arsenicals, permits citation from the remaining 'classical' toxicological aspects, especially from

Address for correspondence: Vladimir Bencko, Institute of Hygiene and Epidemiology, First Faculty of Medicine, Charles University, Prague, Czech Republic E-mail: vladimir.bencko@lf1.cuni.cz

Received: 26 January 2017; accepted: 15 March 2017; first published on June 2017 books and review articles. The citation of original papers is limited and serves for the documentation of highlights in the text, or for the illustration of unique human exposure situations [1].

The highly toxic gas arsine $\left(\mathrm{AsH}_{3}\right)$ is not used as a pesticide and ordinarily plays no part in the danger of arsenical pesticides. However, arsine caused the illness of eight children and one adult, who 48 hours earlier, had helped to clean a dip vat that had been charged with chlordimeform and monobasic calcium phosphate. All of the patients showed albuminuria, and some showed haematuria, abdominal pain, dysuria, and headache. A diagnosis of arsine poisoning was made, even in the absence of any known source of arsenic. However, the next day, the farmer recalled that an arsenical dip had been used in the vat two years earlier, and arsenic was measured later in the acid mud ( $\mathrm{pH}$ 6.5) of the vat and in the urine of the patients. Fortunately (and consistently with the delayed onset), all the cases were mild and the recoveries complete [9].

Elementary arsenic forms two oxides: the trioxide, $\mathrm{As}_{2} \mathrm{O}_{3}$, and the pentoxide, $\mathrm{As}_{2} \mathrm{O}_{5}$. Arsenic trioxide (trivalent) reacts with water to form arsenous acid, $\mathrm{H}_{3} \mathrm{AsO}_{3}$, which is known only in solution; it forms three series of salts: orthoarsenites (e.g., $\mathrm{Na}_{3} \mathrm{AsO}_{3}$ ), metaarsenites (e.g., $\mathrm{NaAsO}_{2}$ ), and pyroarsenites (e.g., $\mathrm{Na}_{4} \mathrm{As}_{2} \mathrm{O}_{5}$ ). Arsenic pentoxide (pentavalent) reacts with 
water to form three acids that may be isolated: orthoarsenic acid, $\mathrm{H}_{3} \mathrm{AsO}_{4}$ metaarsenic acid, $\mathrm{HAsO}_{3}$ and pyroarsenic acid, $\mathrm{H}_{4} \mathrm{As}_{2} \mathrm{O}_{7}$. These acids form the corresponding salts: orthoarsenates, metaarsenates, and pyroarsenates. A few organic arsenic compounds were also used as pesticides. It is beyond the scope of this paper to discuss in detail the highly toxic compounds of arsenic (arsine and certain war gases), or those of low toxicity employed therapeutically in medicine and agriculture (drugs and feed additives)[1].

Arsenites are more soluble and more rapidly toxic than corresponding arsenates; therefore, arsenites were used as rodenticides and herbicides and in insecticidal baits. Paris green, although an arsenite, may be applied to foliage, but inorganic arsenates are less phytotoxic and, therefore, preferred for application to crops as insecticides. Some organic arsenates (dimethylarsinic acid and disodium methyl arsenate) have been used as herbicides[1].

The principal arsenicals produced for use in agriculture, including viniculture, were sodium arsenite $\left(\mathrm{Na}_{2} \mathrm{HAsO}_{3}\right)$, calcium arsenite $\left(\mathrm{Ca}\left(\mathrm{AsO}_{2}\right)_{2}\right)$, copper acetoarsenite-Paris Green $\left(\mathrm{Cu}\left(\mathrm{CH}_{3} \mathrm{COO}\right)_{2}-3 \mathrm{Cu}\left(\mathrm{AsO}_{2}\right)_{2}\right)$, copper pyroarsenite $\left(\mathrm{Cu}_{2} \mathrm{As}_{2} \mathrm{O}_{5}\right)$, calcium arsenate $\left(\mathrm{Ca}_{3}\left(\mathrm{AsO}_{4}\right)_{2}\right)$, and sodium arsenate $\left(\mathrm{Na}_{2} \mathrm{HAsO}_{4} \cdot 12 \mathrm{H}_{2} \mathrm{O}\right)$. Substantial amounts of methylarsenic acid and dimethylarsenic acid are used as selective herbicides to control Johns grass (Sorghum halepsense) in cotton fields and crabgrass in lawns [10]. Arsenic is also an active component of antifungal wood preservatives (e.g., Wolman's salt that contains $25 \%$ sodium arsenite). Lesser amounts are still used in the pharmaceutical and glass industries, in the manufacturing of antiparasitic baths and leather preservatives, for the preparation of hunting trophies in, poisonous baits, in the manufacturing of locust control agents, and in some herbicides (e.g., dimethylarsinic acid was the Agent Blue used by U.S. troops in Vietnam)[1].

During the Vietnam War (1960 - 1971), herbicides were sprayed by U.S. military forces at a rate of an order of magnitude greater than amounts used for domestic weed control [11]. The herbicides were stored and shipped in 208-litre barrels, and named after the coloured band painted on each barrel [12]. They were mostly sprayed over the forests of South Vietnam to kill crops in order to deprive the Vietcong and North Vietnamese troops of food, and to remove the vegetation cover used for concealment, making ambushes more difficult [13].

U.S. soldiers used mortars and grenades in an attempted to destroy rice paddies and rice stocks, but rice grains were very durable and not easily destroyed. Soon, the 'rice-killing operations' became more sophisticated. Rubber or plastic bladders were dropped directly into rice paddies, exploding on impact and releasing toxic herbicides, and barrels of herbicides were also dropped into the water irrigating rice paddies, polluting rivers and poisoning the soil and people for many years [14].

Agent Blue was used as a contact herbicide in South Vietnam for rapid defoliation, grassy plant control and rice destruction. Blue was the agent of choice for the destruction of rice crops. More than four million litres of Agent Blue (also known as Phytar 560-G), were dispensed in the Department of Defense (DOD) herbicide programme, according to military herbicide records [15].

Agent Blue works by rapidly defoliating or dessicating a wide variety of plant species of grasses and grains [16]. It works by uncoupling phosphorylation in plants [17]. It was used in situations requiring rapid defoliation, causing browning or discoloration within one day, with maximum desiccation and leaf fall occuring within two to four weeks [18]. By starving rice plants of moisture, the enemy (including millions of rice-growing villagers) would be starved of their most basic food. This formed an essential part of the U.S. government's 'rice-killing operations' [19].

The term 'Agent Blue' was first applied to cacodylic acid in powder form that was mixed with water in the field. Cacodylic acid is a highly-soluble organic arsenic compound that readily breaks down in soil [15]. It is considered to have very low toxicity for mammals [16]. The original commercial form of Agent Blue was so common and so profitable that it was among 10 toxic insecticides, fungicides and herbicides partially deregulated by the U.S. Environmental Protection Agency (EPA) in February 2004, and specific limits on toxic residues in meat, milk, poultry and eggs were removed [14].

However, in 2009, the U.S. Environmental Protection Agency issued a cancellation order to eliminate and phaseout the use of organic arsenical pesticides by 2013, with one exception - monosodium methanearsonate (MSMA), a broadleaf weed herbicide for use on cotton. Small amounts of cacodylic acid (or disodium methanearsonate) were historically applied as herbicides in cotton fields, golf courses, backyards and other areas, but its use is now prohibited under the U.S. EPA 2009 organic arsenical product cancellation $[14,20]$. Other organic arsenicals (e.g. roxarsone, arsanilic acid and its derivatives) are used as feed additives for poultry and swine to increase the rate of weight gain, improve feed efficiencies, pigmentation, and to treat and prevent disease $[21,22]$.

The highest exposure in insecticide manufacturing was usually found at the mixing, screening, drying, bagging, and drum-filling operations. During these operations, reported arsenic concentrations in air ranged from $0.5-45 \mathrm{mg} / \mathrm{m}^{3}$ [23]. The World Health Organization (WHO) guidelines for the safety limit of arsenic is at $10 \mu \mathrm{g} / \mathrm{L}$ in drinking water [24]. In Vietnam, the legal arsenic concentration limit is five times higher than in the WHO guidelines [25].

The ground waters of the Red River alluvial tract in Hanoi are anoxic and rich in iron due to naturally occurring organic matter in the sediments [25]. The problems are caused largely by the 'tube wells', which draw water from depths of between approximately 30 feet and 120 feet. The wells, designed to provide safe drinking water by avoiding polluted surface waters, inadvertently tapped into arsenic-contaminated underground aquifers [26]. The use of Agent Blue during the Vietnam War and other industrial developments caused the levels of bio-available arsenicals to spike dangerously [27]. The arsenic contamination levels varied from $1-3,050 \mu \mathrm{g} / \mathrm{L}$, with an average arsenic concentration of $159 \mu \mathrm{g} / \mathrm{L}$ in rural groundwater samples from private small-scale tube wells. In a highly affected rural area, the groundwater used directly as drinking water had an average concentration of $430 \mu \mathrm{g} / \mathrm{L}$. Analysis of raw groundwater pumped from the lower aquifer for the Hanoi water supply yielded arsenic levels of 240-320 $\mu \mathrm{g} / \mathrm{L}$ in three of eight treatment plants and $37-82 \mu \mathrm{g} / \mathrm{L}$ in another five plants. Aeration and sand filtration applied in the treatment plants to remove iron lowered the arsenic concentrations to $25-91 \mu \mathrm{g} / \mathrm{L}$, but $50 \%$ remained above the Vietnamese standard of $50 \mu \mathrm{g} / \mathrm{L}$. The arsenic in the sediments may be associated with iron oxyhydroxides and released into the ground water by reductive dissolution of iron. The 
oxidation of sulfide phases could also release arsenic to the groundwater, but sulfur concentrations in sediments were below $1 \mathrm{mg} / \mathrm{g}$. The high arsenic concentrations found in the tube wells ( $48 \%$ above $50 \mu \mathrm{g} / \mathrm{L}$ and $20 \%$ above $150 \mu \mathrm{g} / \mathrm{L}$ ) indicate that several million people consuming untreated groundwater in rural areas might be at a considerable risk of chronic arsenic poisoning [25]. According to Berg [26], arsenic contamination levels in aquifers of Vietnam are of the same order of magnitude as in Bangladesh, where tainted groundwater contributed to what a World Health Organization report called 'the biggest poisoning of a population in history'.

Toxicity of Agent Blue. Agent Blue contained 4.7\% cacodylic acid (also known as hydroxydimethyarsinine oxide or dimethylarsenic acid - DMAA), and 26.4\% sodium cacodylate as the active ingredients $[12,16]$. Cacodylic acid is a colourless, odourless, and hygroscopic crystalline solid. It was also commercially available in the form of soluble concentrates. Water solutions of cacodylic acid are sometimes dyed blue [28]. Cacodylic acid is 54\% arsenic [29]. Besides DMAA, another organic arsenical compound which forms the active ingredient of pesticides and herbicides used mainly for weed control is monomethylarsonic acid (MMAA). MMAA and DMAA are also metabolites of inorganic arsenic formed intra-cellularly by most living organisms (animals, plants and bacteria) [30].

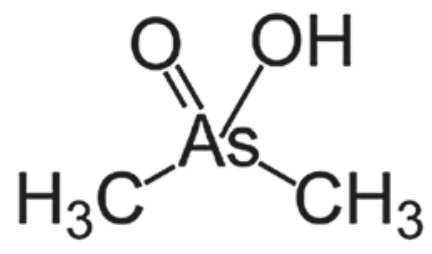

Figure 1. Cacodylic acid (http://en.wikipedia.org/wiki/File:Cacodylic-acidtetrahedral.png)

The routes of entry of cacodylic acid are by ingestion, inhalation, eye contact (irritant), and absorption through the skin[28, 31]. Cacodylic acid is more readily absorbed into the bloodstream when inhaled [17]. It is metabolized by the liver and bioaccumulates in and is excreted by skin, nails and hair [32].

Unlike inorganic arsenicals, DMAA and MMAA do not bind strongly to molecules in humans. Hence, their acute toxicity seem to be less than that of the inorganic arsenicals [33]. However, recent studies indicate that trivalent organic arsenicals [e.g., MMA(III) and DMA(III)] that are metabolic products of inorganic arsenic, could possibly be more toxic than the parent compound $[34,35]$. The mechanism of toxicity of arsenic include enzyme inhibition and oxidative stress, as well as immune, endocrine, and epigenetic effects [36].

Analytical determinations of arsenic poisoning may be made by examining arsenic levels in urine, hair and toenails. Communities and individuals relying on groundwater sources for drinking water need to measure arsenic levels to ensure that their supplies are safe, and communities with arsenic levels greater than $5 \mu \mathrm{g} / \mathrm{L}$ in drinking water should consider a programme to document arsenic levels in the population [37].

\section{ACUTE ADVERSE HUMAN HEALTH EFFECTS OF ARSENICAL PESTICIDES}

Acute poisoning symptoms and signs usually appear within one hour after ingestion. In individuals who were severely exposed to organic arsenicals, a garlicky odour of the breath and faeces are experienced, and there may also be a salty, metallic taste in the mouth, along with abdominal discomfort[17]. Vomiting may also occur, as well as profuse and watery diarrhea, followed by dehydration, electrolyte imbalance, and gradual fall in blood pressure [14].

Acute effects on the central nervous system start as dizziness, headache, drowsiness and confusion, and may progress to weakened muscles, spasms, convulsions, stupor, general paralysis, coma, and possible death within 3-14 days. Death is usually the result of circulatory failure, and possibly renal injury $[14,17]$. The oral lethal dose of fifty, or LD50 for cacodylic acid in rats, is $644 \mathrm{mg} / \mathrm{kg}$ [31].

Skin contact may cause irritation, burns, rash and loss of pigment. Eye contact may cause irritation, conjunctivitis and burns. Inhalation of cacodylic acid may irritate the nose and throat, and cause ulcers to form on the nasal septum, as well as perforations [38].

A study concluded that the inhibition of glucose uptake may contribute to the acute toxicity, especially of organic arsenicals, by further aggravating the depletion of intracellular carbohydrates [39].

\section{CHRONIC ADVERSE HUMAN HEALTH EFFECTS OF ARSENICAL PESTICIDES}

Because the arsenic poisoning of humans can occur by gradual accumulation of small doses until lethal levels are reached, the use of Agent Blue and other organic arsenicals may pose a long-term danger [29]. Neurological symptoms are usually more frequent than gastrointestinal effects over prolonged exposure of organic arsenicals [17]. Cacodylic acid may cause parasthesias and/or weakness in the hands and feet [38].

The IARC classifies DMAA and MMAA as possibly carcinogenic to humans (Group 2B). Arsenobetaine and other organic arsenic compounds not metabolized in humans are not classifiable regarding their carcinogenicity for humans (Group 3) [40]. DMAA induces single strand breaks in DNA, an organ-specific lesion, in the lungs of both mice and rats and in human lung cells in vitro. This damage may be mainly due to the peroxyl radical of DMA and production of reactive oxygen species by lung tissues [41].

Farmers exposed to arsenic pesticides are at risk of occupational skin cancer, mostly Bowen's disease (carcinoma in situ), multiple basal cell carcinomas and squamous cell carcinomas. Non-arsenic pesticides, e.g. paraquat, are also potentially carcinogenic [42].

Multi-organ initiation-promotion studies have demonstrated that DMAA acts as a promotor of urinary bladder, kidney, liver and thyroid gland cancers in rats, and as a promotor of lung tumours in mice [41]. Lifetime exposure to DMA in diet or drinking water also causes a dose-dependent increase in urinary bladder tumours in rats $[41,43]$. DMAA also has the potential to promote rat liver carcinogenesis, possibly via a mechanism involving stimulation of cell proliferation and DNA damage caused by 
oxygen radicals [44]. Besides this, DMAA has a promoting effect on skin tumourigenesis in K6 / ODC transgenic mice [45]. Furthermore, DMAA strongly promotes tumorigenesis initiated by 4 -nitroquinoline 1-oxide in the lungs of mice [46]. It has been proposed that cacodylic acid may cause lung carcinomas [32]. Pulmonary carcinogenesis may result from high-dose exposure to cacodylic acid because both inorganic arsenic and cacodylic acid share dimethyland tri-methylarsine as metabolites; the former has been associated with DNA damage in both rat and mouse lung tissue after high-dose oral acute exposures. Excess lung cancer has been reported in epidemiologic studies of smelter workers who were occupationally exposed primarily to pentavalent arsenic [47].These and many more studies suggest that DMAA may play a role in the carcinogenesis of inorganic arsenic [41]. However, much of the carcinogenicity effect of organic arsenicals in humans still remain unknown.

The serious suspicion that arsenic can cause blastic transformation of cells is the reason for several authors stressing the necessity to exclude arsenic from drugs used for human therapy. Such a prohibition was introduced, for example, in the mid-sixties in Czechoslovakia, where the use of arsenic drugs in human therapy was forbidden, with the exception of those applied in the treatment of acute promyelocytic leukemia and protozoal infections [48].

A study by Irvine et al. concluded that the margins of exposure estimated based on conservative estimates of daily intakes of arsenic in all of its forms, indicate that exposure to MMAA or DMAA at environmentally-relevant exposure levels, by the oral route is unlikely to pose a risk to pregnant women and their offspring [30].In another study involving animals, cacodylic acidwas administered to time-pregnant albino CD rats and CD-1 mice on days 7-16 of gestation, by gastric intubation as a solution in distilled water. Foetal and maternal toxicity was observed in both species. In the mouse, maternal toxicity was evident at the lowest dose, while teratogenic response was confined to cleft palate at 400 and $600 \mathrm{mg} / \mathrm{kg} /$ day. The effective maternal toxic dose in the rat was $40 \mathrm{mg} / \mathrm{kg} /$ day. In this species, the incidence of irregular palatine rugae, i.e., ridges that were discontinuous and/or not lying in apposition at the palatal raphe, was significantly dose-related. The results suggest an 'apparent no effect level' for this anomaly below $30 \mathrm{mg} / \mathrm{kg} /$ day [49].

Repeated skin contact may cause hyperpigmentation and keratosis. Malnourished people have been shown to be more predisposed to arsenic-related skin lesions[37]. White bands may form across the nails [17].

\section{CONCLUSIONS}

Such are the acute and chronic effects of commercial organic arsenical herbicides which were used in a less toxic formulation than Agent Blue. Thus, we can expect a much worse impact on those who were directly exposed to or directly handling Agent Blue in rice paddies during the Vietnam War [14]. Although the acute and chronic effects of organic arsenicals are not as many as those of the inorganic arsenicals, organic arsenicals still have a great impact on human health, which could be greater still as more studies in the future may uncover more of its currently unproven or unknown health effects.

The mass use of arsenicals as pesticides, growth stimulators and wood preservatives is now just a part of our history.
The use of arsenical pesticides in agriculture has decreased dramatically, following the introduction of DDT, which was then subsequently replaced by more environmentally-friendly insecticides. These new insecticides are now, in the optimal case, used within an integrated, pest management concept. Such a concept represents an ecological approach which utilizes a variety of interventions that are both economically acceptable, as well as environmentally and socially sound[1].

The present public health concern related to human exposure to arsenic is tightly bound with the consumption of arsenic rich drinking water (e.g., in Bangladesh, Inner Mongolia, and other territories). This is grounded in specific geological reasons which have been briefly mentioned in this review[1].

Current epidemiological and experimental studies have attempted to elucidate the specific mechanism of arsenic carcinogenicity. This has led to the question of whether arsenic is a true genotoxic carcinogen, or whether it is an epigenetic carcinogen. Due to the complexity of its mechanisms of toxicity on a molecular level, and because of genetic polymorphism in the human population, both options continue to remain plausible [1].

\section{Acknowledgements}

The review paper was elaborated within research activities supported by projects PROGRES Q29/LF1 and by the preparatory phase of GACR17-00859S grant.

\section{REFERENCES}

1. Bencko V, Slámová A.Best practices for promoting farmers' health: the case of arsenic history. J Public Health. 2007; 15: 279-288.

2. IARC (International Agency for Research on Cancer)Monographs, Supplement 4. Evaluation of the Carcinogenic Risks of Chemicals to Humans, Chemicals, Industrial Processes and Industries Associated with Cancer in Humans. International Agency for Research on Cancer. Lyon, 1982.

3. EPA (U.S. Environmental Protection Agency). Health Assessment Document for Inorganic Arsenic. Final Report. D. Jacobson-Kram, et al. Environmental Criteria and Assessment Office, EPA. Research Triangle Park, N.C, 1984.

4. ATSDR. Toxicological profile for arsenic. U.S. Dept. of Health and Human Services. Atlanta, Georgia, 2007.

5. Fowler BA. Biological and environmental effects of arsenic. Vol.6. Elsevier, Amsterdam, 1983.

6. Bencko V. Arsenic. In: Fishbein L, Furst A, Mehlman MA (Eds) Genotoxic and carcinogenic metals: Environmental and occupational exposure. Advances in Modern Environmental Toxicology. Princeton, New Jersey, Sci Publ, 1987; 11: 1-30.

7. Ishinishi N, Tsuchiya K, et al. Arsenic. In: Handbook on the Toxicology of Metals, Vol. 2, 2nded. (Friberg L, Nordberg GF, Vouk VB, eds.) Elsevier, Amsterdam, 1986.

8. Clarkson TW. Inorganic and Organometal Pesticides. In: Krieger RI, Handbook of pesticide toxicology, Agents. Academic Press, San Diego, 2001; pp. 1358-1428.

9. Rathus E, Stinton RG, Putnam JL. Arsine poisoning, country style. Med J Aus. 1979; 1: 163-6.

10. WSSA (Weed Science Society of America). 1974.

11. Stellman JM, Stellman SD, et al. The extent and patterns of usage of Agent Orange and other herbicides in Vietnam. Nature. 2003; 422: 681-687.

12. Young AL. The History, Use, Disposition and Environmental Fate of Agent Orange. Springer, NY, 2009. ISBN: 978-0-387-87485-2.

13. Buckingham WA Jr. Operation Ranch Hand: Herbicides in Southeast Asia. Air University Review, 1983.http://www.airpower.maxwell.af.mil/ airchronicles/ aureview/1983/Jul-Aug/buckingham.html

14. Greenfield G. Agent Blue and the Business of Killing Rice. Zmag. 2004, June 18. http://www.countercurrents.org/us-greenfield180604.htm

15. IOM (Committe to Review the Health Effects in Vietnam Veterans of Exposure to Herbicides, Division of Health Promotion and Disease 
Prevention, Institute of Medicine). Veterans and Agent Orange: Health Effects of Herbicides Used in Vietnam. National Academy Press, Washington DC, 1994.

16. Hood RD. Cacodylic acid: Agricultural Uses, Biological Effects, and Environmental Fate. Veterans Administration, Agent Orange Projects Office, Washington, DC, 1985.

17. Fishel FM. Pesticide Toxicity Profile: Arsenical Herbicides. PI-89. Pesticide Information Office, Florida Cooperative Extension Service, Institute of Food and Agricultural Sciences, University of Florida, 2005. (Revised in 2011). http://edis.ifas.ufl.edu/pdffiles/PI/PI12600.pdf

18. Darrow RA, Irish KR, Minarik CD. Herbicides Used in Southeast Asia Kelly AFB, TX, 1969. Technical Report SAOQ-TR-69-11078. 60 pp.

19. Mohr C. U.S. Spray Destroys Rice in Vietcong Territory. The New York Times, 21 Dec 1965.

20. EPA (U.S. Environmental Protection Agency). Organic arsenicals; Product Cancellation Order and Amendments to Terminate Uses (EPA-HQ-OPP-2009-0191; FRL-8437-7) 2009.

21. FDA (Food and Drug Administration). Arsanilic acid (21CFR558.62), pp. 413-414. 2008.

22. FDA (Food and Drug Administration). Roxarsone (21CFR558.530), pp. 500-503. 2008.

23. Patty FA. Industrial Hygiene and Toxicology, 2nd ed. John Wiley, NY, 1962.

24. WHO (World Health Organization). 12.8 Arsenic. In: 12. Chemical Fact Sheets. 2003 http://www.who.int/water_sanitation_health/dwq/ en/gdwq3_12.pdf

25. Berg M, Tran HC, et al. Arsenic contamination of groundwater and drinking water in Vietnam: a human health threat. Environ Sci Technol. 2001; 35: 2621-2626.

26. ACS (American Chemical Society). Northern Vietnam Drinking Water Contains Dangerous Arsenic Levels. ScienceDaily. 2001. http://www. sciencedaily.com/releases/2001/07/010706081137.htm

27. Ly TM. Arsenic Contamination in Groundwater in Vietnam: An Overview and Analysis of the Historical, Cultural, Economic, and Political Parameters in the Success of Various Mitigation Options. Pomona Senior Theses. Paper 41. 2012. http://scholarship.claremont. edu/pomona_theses/41

28. OSHA (Occupational Safety and Health Administration). Occupational Safety and Health Guideline for Arsenic. U.S. Dept. of Labor 1996. http://www.osha.gov/SLTC/ healthguidelines/arsenic/recognition.html

29. SBSG (Stanford Biology Study Group). The Destruction of Indochina. Science and Public Affairs. 1971; 27: 36-40.

30. Irvine L, Boyer IJ, DeSesso JM. Monomethylarsonic acid and dimethylarsinic acid: developmental toxicity studies with risk assessment. Birth Defects. Res B Dev Reprod Toxicol. 2006; 77: 53-68.

31. Sciencelab.com, Inc. Cacodylic acid MSDS (Material Safety Data Sheet). 2005. http://www.sciencelab.com/msds.php?msdsId=9927472

32. Hayes W Jr. Pesticides studied in man. Williams and Wilkins, Baltimore, 1982. ISBN-13: 978-0683038965.
33. Abernathy CO, Ohanian EV. Health effects of inorganic arsenic in drinking water. Proc. AWWA WQTC, Miami, Fla., Nov 7-11, 1993.

34. Petrick JS, Jagadish B, et al. Monomethylarsonous acid (MMA(III)) and arsenite: $\mathrm{LD}(50)$ in hamsters and in vitro inhibition of pyruvate dehydrogenase. Chem Res Toxicol. 2001; 14: 651-656.

35. Styblo M, et al. Comparative toxicity of trivalent and pentavalent inorganic and methylated arsenicals in rat and human cells. Arch Toxicol. 2000; 74: 289-299.

36. Vahter M. Effects of Arsenic on Maternal and Fetal Health. Annual Review of Nutrition. 2009; 29: 381-399.

37. Kapaj S, Peterson H, et al. Human health effects from chronic arsenic poisoning. A review. J Environ Sci Health. A Tox Hazard Subst Environ Eng. 2006; 41: 2399-428.

38. NJ (State of New Jersey). Right to Know Hazardous Substance Fact Sheet: Cacodylic Acid. 1999. (Revised in 2008). http://nj.gov/health/ eoh/rtkweb/documents/fs/0304.pdf

39. Liebl B, Mückter $\mathrm{H}$, et al. Influence of organic and inorganic arsenicals on glucose uptake in Madin-Darby canine kidney (MDCK) cells. Analyst. 1992; 117: 681-684.

40. IARC (International Agency for Research on Cancer). Arsenic and arsenic compounds. IARC Monogr Eval Carcinog Risk Hum. 2012; 100C: 41-93. http://monographs.iarc.fr/ENG/Monographs/vol100C/ mono100C-6.pdf

41. Kenyon EM, Hughes MF. A concise review of the toxicity and carcinogenicity of dimethylarsinic acid. Toxicology. 2001; 160: 227-236.

42. Spiewak R. Pesticides as a cause of occupational skin diseases in farmers. Ann Agric Environ Med. 2001; 8: 1-5.

43. Wei M, Wanibuchi $\mathrm{H}$, et al. Urinary bladder carcinogenicity of dimethylarsinic acid in male F344 rats. Carcinogenesis. 1999; 20: 1873-1876.

44. Wanibuchi H, Hori T, et al. Promotion of rat hepatocarcinogenesis by dimethylarsinic acid: association with elevated ornithine decarboxylase activity and formation of 8-hydroxydeoxyguanosine in the liver. Jpn J Cancer Res. 1997; 88: 1149-1154.

45. Morikawa T, Wanibuchi $\mathrm{H}$, et al. Promotion of skin carcinogenesis by dimethylarsinic acid in keratin (K6)/ODC transgenic mice. Jpn J Cancer Res. 2000; 91: 579-581.

46. Yamanaka K, Ohtsubo K, et al. Exposure to dimethylarsinic acid, a main metabolite of inorganic arsenics, strongly promotes tumorigenesis initiated by 4-nitroquinoline 1-oxide in the lungs of mice. Carcinogenesis. 1996; 17: 767-770.

47. EPA (U.S. Environmental Protection Agency). Cacodylic Acid: Decision Document. EPA, Office of Pesticide Programs, Washington, DC, 1981.

48. Antman K. Introduction: The History of Arsenic Trioxide in Cancer Therapy. The Oncologist. 2001; 6: 1-2.

49. Rogers EH, Chernoff N, Kavlock RJ. The teratogenic potential of cacodylic acid in the rat and mouse. Drug Chem Toxicol. 1981; 4: 49-61. 